\title{
The Impact of Operational Customer Relationship Management on Customer Loyalty
}

\author{
Africa Makasi \\ PhD student, University of KwaZulu-Natal, South Africa and Harare Institute of Technology, Zimbabwe \\ africa.makasi@yahoo.com \\ Fanny Saruchera
}

University of KwaZulu-Natal, South Africa and Chinhoyi University of Technology, Zimbabwe, Africa Makasi. Harare Institute of Technology. Department of Technopreneurship, Zimbabwe.

P.O. Box B.E , 277.Belvedere, Harare, Zimbabwe.

Email: africa.makasi@yahoo.com

\section{Doi:10.5901/mjss.2014.v5n23p291}

\section{Abstract}

The purpose of this paper is to investigate the role of operational customer relationship management (OCRM) on customer loyalty with special reference to the mobile telephone industry in Zimbabwe. Motivation for the research was generated by the need to find out how customer loyalty can be created through OCRM. The research was conducted by reviewing various streams of literature and interviews with 7 representatives from the 3 dominant companies in the industry and 15 sampled customers from these three competing companies in the mobile telephone industry (MTI). A semi-structured questionnaire was used. All qualitative responses were grouped into themes for coding purposes. The data gathered was coded and captured to form panel data for further analysis using the Statistical Package for Social Sciences (SPSSO. Results of the research showed that because of the highly dynamic market environment, consumers have become highly demanding calling for the strategic significance of the intelligent network in OCRM for the creation of customer satisfaction. The research also revealed that increasing organizational performance through operational CRM implementation can increase customer perceived value which results in customer loyalty and competitiveness. Our current research focused on operational CRM's influence on customer loyalty. Future research should assess the impact of analytical CRM on customer loyalty. The measurement and critical analysis of customer life time value against company investments in building loyalty should redirect future research towards this area.

Keywords: Customer relationship management, customer loyalty, stakeholder theory

\section{Introduction}

In Zimbabwe's mobile telecommunications industry, competition is split between three major with the market leader commanding a controlling stake at over $66 \%$ share of the market. The last decade has witnessed a substantial shift in emphasis on the part of many firms from focusing on the products they produce to a concentration on their customers and the value that their customers derive from ownership and use of these products/services. This "customer-centric" perspective is correlated with the blurring of the line between products and services, globalization and growing usage of social networking platforms. Achievement of operational customer relationship management (OCRM) objectives for organizations in MTI remains an elusive goal without efficient and effective contact center operations. Consumers are now well informed and educated thus need for those in the service industry to shift approach in a more radical way in order to survive. This shift towards a service-centric strategy represents an important aspect of firms' efforts towards enhancing overall revenue and profit, customer acquisition and retention, and competitive differentiation. The major question is: in an environment defined by customer control and two-way dialogue, are customers and businesses in sync with each other's expectations? This calls for a radical shift from general CRM of the past to a more collaborative engagement through enhanced operational tools suitable for the $21^{\text {st }}$ century marketer. Even though many corporate leaders recognize the need for OCRM in general, there is little evidence to promote and support OCRM for the creation of loyal customer bases. The challenge is to explore this new dimension of CRM by juxtaposing OCRM on one side and customer loyalty on the other and assess the implications of this relationship. Consequently, this research seeks to provide more evidence on the effectiveness of OCRM in customer loyalty within the mobile Telephone Industry in Zimbabwe. 


\section{Literature Review}

In some organizations, OCRM is simply a technology solution that extends separate databases and sales force automation tools to bridge sales and marketing functions in order to improve targeting efforts (Goldenberg, 2000). In other organizations OCRM is considered as a tool specifically designed for one-to-one customer communications (Peppers and Rogers, 1999). OCRM is not merely technology applications for marketing, sales and service, but rather, when fully and successfully implemented, a cross-functional, customer-driven, technology-integrated business process management strategy that maximizes relationships and encompasses the entire organization (Goldenberg, 2000). OCRM offers customization, simplicity, and convenience for completing transactions, regardless of the channel used for interaction (Gulati and Garino, 2000). OCRM initiatives have resulted in increased competitiveness for many companies as witnessed by higher revenues and lower operational costs. Managing customer relationships effectively and efficiently boosts customer satisfaction and retention rates (Reichheld, 1996a, b; Jackson, 1994; Levine, 1993). In particular, customers benefit from the belief that they are saving time and money as well as receiving better information and special treatment (Kassanoff, 2000). Furthermore, regardless of the channel or method used to contact the company, whether it is the Internet, call centers, sales representatives, or resellers, customers receive the same consistent and efficient service (Creighton, 2000). Thus, Shani and Chalasani (1992) have defined relationship marketing as an integrated effort to identify, maintain, and build up a network with individual consumers and to continuously strengthen the network for the mutual benefit of both sides, through interactive, individualized and value-added contacts over a long period of time. Jackson (1985) applies the individual account concept in industrial markets to suggest OCRM to mean. In other business contexts, Doyle and Roth (1992), O'Neal (1989), and Paul (1988), have proposed similar views of customer relationship management. McKenna (1991) has professed a more strategic view by putting the customer first and shifting the role of marketing from manipulating the customer (telling and selling) to genuine involvement with the customer (communicating and sharing knowledge). Berry (1995), stressed that attracting new customers should be viewed only as an intermediate step in the marketing process and that developing closer relationship with these customers and turning them into loyal ones should be equally important aspects of marketing. His notion of customer relationship management resembles that of other scholars studying services marketing, such as Gronroos (1990), Gummesson (1987), and Levitt (1983). Although each one of them has espoused the value of interactions in marketing and its consequent impact on customer relationships, Gronroos and Gummesson take a broader perspective and advocate that relationships with customers be the focus and dominant paradigm of marketing. For example, Gronroos (1990) states that marketing is to establish, maintain, and enhance relationships with customers and other partners, at a profit, so that the objectives of the parties involved are met. This is achieved by a mutual exchange and fulfilment of promises. Similarly, Morgan and Hunt (1994) draw upon the distinction made between transactional exchanges and relational exchanges by Dwyer, Schurr, and Oh (1987) to suggest that relationship marketing refers to all marketing activities directed toward establishing, developing, and maintaining successful relationships. The core theme of all OCRM and relationship marketing perspectives is its focus on a cooperative and collaborative relationship between the firm and its customers, and/or other marketing actors (Gronroos, 1990).

\subsection{The Purpose of OCRM Formation Process}

The overall purpose of OCRM is to improve marketing productivity and to enhance mutual value for the parties involved in the relationship. Improving marketing productivity and creating mutual values can be achieved by increasing marketing efficiencies and/or enhancing marketing effectiveness (Sheth \& Parvatiyar, 1995a; Sheth Sisodia, 1995). By seeking and achieving such operational goals as lower distribution costs, streamlining order processing and inventory management, reducing the burden of excessive customer acquisition costs and by considering the economics of customer retention, firms can achieve greater marketing efficiencies. They can also enhance marketing effectiveness by carefully selecting customers for their various programs, by individualizing and personalizing their market offerings to anticipate and serve the emerging needs of individual customers, by building customer loyalty and commitment; by partnering to enter new markets and develop new products, and by redefining the competitive playing field for their company (Sheth \& Parvatiyar, 1995). Thus, stating the objectives and defining the purpose of OCRM in a company helps clarify the nature of the OCRM programs and activities that ought to be performed by the partners. Similarly, in the mass-market context, consumers expect to fulfil their goals related to efficiencies and effectiveness in their purchase and consumption behaviour. Sheth and Parvatiyar (1995), contend that consumers are motivated to engage in relational behaviour because of the psychological and sociological benefits associated with reduction in choice decisions. In addition, to their natural inclination to reduce choices, consumers are motivated to seek the rewards and associated benefits offered by OCRM 
programs. Even though a company may serve all customer types, few have the necessary resources and commitment to establish OCRM programs for all. Therefore, in the initial phase, companies have to decide on which customer types and specific customers or customer groups to focus their OCRM efforts on. Subsequently, when a company gains experience and achieve successful results, the scope of CRM activities can be expanded to include other customers in the program or to include additional programs (Shah, 1997).Although partner selection is an important decision in achieving OCRM goals, not all companies have a formalized process of selecting customer partners. Some select customer partners by following the intuitive judgments of their senior managers and select other partners from those customers who demand to be selected. The essence of OCRM programs is customer selectivity (Sheth \& Sisodia, 1995). It has now become common knowledge that the value of all customers is not equal. The $80 / 20$ rule prevails whereby we have learned that 20 percent of customers generate more than 80 percent of revenues for most companies, and it is not uncommon to find that an even lower percentage of customers can generate more than 80 to 90 percent of the revenues (Sheth \& Sisodia, 1995). Under such circumstances, it is not prudent for a company to allocate equal resources to all customers. Customer segmentation and program differentiation is needed in order to match revenue potential with service offerings. Those with higher revenue potential deserve a greater allocation of costs and service (Sheth \& Sisodia, 1995). Experience indicates that defining and measuring brand loyalty is extremely difficult. Researchers have used both attitudinal and behavioural measures to define and assess this variable (Oliver, 1999; Zeithaml, 2000). From an attitudinal perspective, customer loyalty has been viewed by some researchers as a specific desire to continue a relationship with a service provider (Czepiel \& Gilmore, 1987). From a behavioural view, customer loyalty is defined as repeat patronage, that is, the proportion of times a purchaser chooses the same product or service in a specific category compared to the total number of purchases made by the purchaser in that category (Neal, 1999). The dilemma lies in the fact that intention may not lead to action, and repeated buying behaviour may not reflect intentions. Loyalty can be of substantial value to both customers and the firm. Customers are willing to invest their loyalty in business that can deliver superior value relative to the offerings of competitors (Reichheld, 1996). When they are loyal to a firm, consumers may minimize time expended in searching and in locating and evaluating purchase alternatives. Also, customers can avoid the learning process that may consume the time and effort needed to become accustomed to a new vendor. Customer loyalty is one major driver of success in e-commerce (Reichheld \& Schefter, 2000). Loyal customers often will, over time, bring in substantial revenues and demand less time and attention from the firms they patronize. Many customers are inclined to forgive customerservice mishaps, display decreasing sensitivity to price, and disseminate positive word-of-mouth about the business to others. As a result, customer loyalty can be a major source of sustained growth and profit and a strong asset (Anderson \& Mittal, 2000). Thus, because of this gap, current research will endeavour to explore how operational OCRM can be used to build loyalty in customers.

\subsection{Customer-Perceived Value and relationship with OCRM}

Perceived value has its root in equity theory, which considers the ratio of the consumer's outcome/input to that of the service provider's outcome/ input (Oliver \& DeSarbo, 1988). The equity concept refers to customer evaluation of what is fair, right, or deserved for the perceived cost of the offering (Bolton \& Lemon, 1999). Perceived costs include monetary payments and nonmonetary sacrifices such as time consumption, energy consumption, and stress experienced by consumers. In turn, customer- perceived value results from an evaluation of the relative rewards and sacrifices associated with the offering. Customers are inclined to feel equitably treated if they perceive that the ratio of their outcome to inputs is comparable to the ratio of outcome to inputs experienced by the company (Oliver \& DeSarbo, 1988). In this regard, Sirdeshmukh, Singh, and Sabol (2002) argue that customer value is a superordinate goal and customer loyalty is a subordinate goal, as it is a behavioural intention. According to goal and action identity theories, a superordinate goal is likely to regulate subordinate goals. Thus, customer value regulates "behavioural intentions of loyalty toward the service provider as long as such relational exchanges provide superior value" (Sirdeshmukh et al., 2002, p. 21). Prior empirical research has identified perceived value as a major determinant of customer loyalty in such settings as telephone services (Bolton \& Drew, 1991), airline travel, and retailing services (Sirdeshmukh et al., 2002). Chang \& Wildt (1994, report that customer-perceived value has been found to be a major contributor to purchase intention. Customer satisfaction remains a worthy pursuit among the consumer marketing community (Oliver, 1999). The transaction-specific approach defines customer satisfaction as an emotional response by the consumer to the most recent transactional experience with an organization (Oliver, 1993). The associated response occurs at a specific time following consumption, after the choice process has been completed. On the other hand, the overall satisfaction perspective views customer satisfaction in a cumulative evaluation fashion that requires summing the satisfaction associated with specific products and various facets of the firm. Some researchers (Cronin \& Taylor, 1992; Parasuraman, 
Zeithaml, \& Berry, 1988) consider overall satisfaction to be primarily a function of perceived service quality. Compared to transactional-specific satisfaction, overall satisfaction reflects customers' cumulative impression of a firm's service performance. In turn, it may serve as a better predictor of customer loyalty. In the setting of online services, customer satisfaction can be explained by traditional models and two additional conceptual paradigms. The first is the technology adoption model, which proposes that customer intention to adopt a new information technology is primarily determined by the ease of use and the usefulness of the technology (Davis, 1989; Davis, Bagozzi, \& Warshaw, 1989). Satisfied customers tend to have a higher usage level of a service than those who are not satisfied (Bolton \& Lemon, 1999; Ram \& Jung, 1991). They are more likely to possess a stronger repurchase intention and to recommend the product/service to their acquaintances (Zeithaml et al., 1996). Numerous studies have revealed that customer satisfaction positively affects loyalty (Bloemer, de Ruyter, \& Wetzels, 1999; Oliver, 1999; Zeithaml et al., 1996). This relationship would seem to be applicable to Internet e-commerce (Reichheld, Markey, \& Hopton, 2000). Therefore, current research will seek to identify ways of enhancing satisfaction through operational CRM.

\subsection{Creating customer satisfaction through use of call centre}

Call centers now serve as the "public face" for many firms, there is increasing executive consideration of their vital role in customer acquisition and retention. Similarly, the managerial awareness of call centers' potential to generate significant incremental revenue by augmenting service encounters with potential sales opportunities has also been growing rapidly: for example, a recent McKinsey study revealed that credit card companies generate up to $25 \%$ of new revenue from inbound call centers (Eichfeld, Morse, and Scott 2006). However, for call center managers, there is significant additional complexity associated with managing this dual service-and-sales role without compromising response times, service quality, and customer satisfaction. The relationship between customer satisfaction and profitability and stock price has been well established empirically through the American Customer Satisfaction Index Fornell et al. (2006). In addition, the impact of the customer service experience on customer satisfaction and retention has been studied by several researchers, including Johnston (1998), Goodman and Newman (2002), and Chebat, Davidow, and Codjovi (2005). One of the key findings from these streams of research is that the vast majority of dissatisfied customers do not complain but are nevertheless at much greater risk of abandoning their relationship with the company as a consequence of their unhappiness. The importance of the call center in this relationship is underscored by a recent study that asserted that $80 \%$ of a firm's interaction with its customers is through call centers, and $92 \%$ of customers form their opinion about a firm based on their experience with call centers (Anton, Setting, and Gunderson 2004). Gans (2002), explores this phenomenon in the context of repeated customer interactions with a group of competing suppliers, modeling customer choice as a function of the quality of previous interactions with a given supplier. The results showed that the quality of customers' experience with a particular firm will have a major impact on that firm's long-term market share. A great challenge for managers, both in the call center and in other parts of the organization, is to determine how to leverage the contents of these systems to reduce costs and improve the company's relationship with its customers. Mehrotra and Grossman (2006) describe process improvement methods for a consumer software company's technical support call center. Utilizing CRM data captured during customer phone calls, analysts were able to quantify the impact of specific issues on call volumes and work with the product marketing, engineering, and documentation groups to eliminate specific problems from future software releases. The result of these processes was a lower per-customer call arrival rate, as well as increased customer satisfaction. Sun and Li (2006) use CRM data about service durations and customer retention in conjunction with an adaptive customer learning model (Sun, Li, and Zhou 2006) to suggest policies for distributing calls from different types of customers across heterogeneous on- and offshore call centers within the same network, while considering both short-term and long-term customer economic implications for the firm (Sun and Li, 2006).

\subsection{Using OCRM for relationship marketing}

Within this new paradigm, interacting with customers and satisfying customer needs are vitally important (Christou, 2003b). Customer relationships are not built and sustained with direct (e)-mail themselves, but rather with the types of programmes and communication strategies that are available and for which e-mail may be a delivery mechanism. Winer (2001) argued that a comprehensive OCRM is a collection of integrated components such as customer service (0800 numbers, faxback/customer comments cards, e-mail, FAQ), frequency, loyalty and reward programmes, customization and community building (e.g. virtual communities). The aim of these integrated customer communication channels is to support the customer cycle (i.e. acquisition, enhancement/cross-up-selling and retention) by identifying profitable customers, differentiating the services/products offered to different markets of ones, interact with individual customers in 
an integrated way across channels and customize/personalize customers' experiences. For dealing with employees' experience-related desires, employees will be required to have advanced social skills such as understanding of role conflict, role theory, communications and personality identification (Olsen and Connolly, 2000). Employees will need to be content experts who do not only know how to work with and exploit technology, but also can manage the information exchange and match guests to experiences. Moreover, as such knowledge-based work may take place electronically; staff should be able and know how to work collaboratively and electronically irrespective of their spatial, time and cultural differences (Olsen and Connolly, 2000). Data warehouses and data mining are the most popular and highly needed systems for providing OCRM capabilities or else for defining, developing and managing "the segment of one" (Olsen and Connolly, 2000). Wells et al. (1999) described how electronic networks allow the distribution and share of customer databases across the company's branches.

\subsection{OCRM's influence on Consumer Perceptions}

Positive customer perception about product quality and safety leads to increased sales or decreased costs associated with stakeholder relationships (Waddock and Graves, 1997). Higher product safety and quality improves the bottom line (Berman et al., 1999). In product retailing, market reactions are found to be negative for socially irresponsible companies (Bromiley and Marcus, 1989; Davidson and Worell, 1988). When customers are dissatisfied with a product or its associated services, investors apprehend that negative customer reactions in the form of decreased patronage, lawsuits, or both, will directly affect the bottom line (Berman et al., 1999). Event studies establish that market value of a company decreases when corporate irresponsibility and illegal behavior is observed (Frooman, 1997) but no research has attempted to find out the composite impact of internal and external customers on corporate images (Bromiley and Marcus, 1989; Davidson and Worell, 1988). CRM implementation is a holistic and complex notion, which organized around business processes, information technology integration (Piskar and Faganel, 2009; Bull, 2003), business process re-engineering and organizational learning centralized to a shared vision (Chang 2007). People, process and technology are the key in the implementation of OCRM (Chen and Popovich, 2003; Zablah et al., 2004). Business strategy, current organizational capabilities and a sound reason of implementing OCRM in the organization is the pre-requisites for a successful OCRM implementation (Nguyen et al., 2007). Gillies et al., (2002) discussed that a strategy which is based on the segmentation of customers is stipulated for implementing a sound OCRM solution. Customers must be integrated in the CRM implementation process as customer integration in the process of OCRM implementation can turn the customers loyal towards the organization (Wetsch, 2006). Osman \& Hemmington (2008), stressed on transactional marketing rather than relational marketing. Fletcher and Wright (1996) affirmed that successful OCRM implementation mandates full support and commitment of top management. Sigala (2004) evinced that perceived OCRM goals are met when the corporate goal for ICT (Information, Communication and Technology) are put together with a focus on OCRM applications. Wells et al. (1999), illustrated the key elements for OCRM implementation as business process analysis, redesign of customer data, accessibility of organizational information, and ICT enabled customer interaction. According to them, these four elements are very progressive in successful OCRM implementation. Sigala (2005), suggested the organization of business processes, comprehensive understanding of the customer base and technology for implementation of OCRM. Emperger (2004), highlighted the authoritative extracts from qualitative analysis of his study, i.e. guest profile management, campaign management and security, referred the appointment of external consultants or OCRM software companies to alter the business culture of the hotel company as customer focus mandates change in business procedures. Lo et al. (2010) pointed out CRM activities in the hotel industry, which helps hoteliers to conceive a better understanding of customers' requirements and expectations, managing the need of customers and life cycle of the customers. Sigala and Christou (2002), notified that OCRM is an influential strategy to gain competitive advantage in current market scenario. Sigala (2005), in her study coined that OCRM is an imperative strategy for attracting and magnifying the guest patronage in the hotel industry. O'Connor and Murphy (2004), in their review on hospitality research argued that researchers should enlarge their thinking process and should focus to enrich the areas like management of IT resources in the hospitality industry. Chang (2007), in his research pointed a thought on implementation of customer relationship management, which consists business process re-engineering and organizational learning. Furthermore, he augmented that if OCRM is implemented with the factors, which is said to be relationship quality that will convert into a good organizational performance. Piccoli et al. (2003), stressed on increasing customer loyalty to enhance the organizational performance and remarked that effective OCRM implementation can increase customer satisfaction which results in customer loyalty, therefore customer acquisition costs will go down and overall performance of the organization will automatically improve. Although, it is said that OCRM strategies are imperative for organizational performance but its implementation issue can have both positive and negative effects (King and Burgess, 2007). Furthermore, they disclosed 
that more than 50 percent of OCRM projects fail due to some implementation issues.

\section{Methodology}

A quantitative research approach was used for this study. What constitutes a quantitative research method is the involvement of a numeric or statistical approach to the research design (Creswell, 2007). The findings from quantitative research can be predictive, explanatory, and confirming. Quantitative research also involves data collection that is typically numeric and the researcher tends to use mathematical models as the methodology of data analysis. The general design of the research was a descriptive research study which demanded researching and describing the strategic factors of OCRM approaches that influence customer loyalty in the MTI in Zimbabwe. This was an appropriate design since the major objective was to find out from the executives and customers and then describe the strategic relationship between operational CRM and achievement of loyalty from the existing customer base. This was done for several reasons. Firstly, a quantitative study provided a means of revealing complex facets of consumers' perceptions at different levels of associations and specificity. Also, based on the available literature, the vast majority of research studies on OCRM and its influence on customer loyalty are based on quantitative research. Secondly, quantitative interviewing was relevant for this study because it put emphasis on the interviewee's point of view instead of reflecting the researcher's interests as in quantitative research and seeks for detailed, complex answers. Participants willing to take part in the survey were contacted via an e-mail invitation that gave them information regarding the interviews. The e-mail also contained information about the place and time of the meetings as well as information assuring them that their identities will be kept confidential.

\subsection{Sampling Method}

Since this study used qualitative research methodology, non-probability sampling was employed to help select companies and consumer participants for inclusion in the sample. In non-probability sampling, units or people are selected based on the judgement of the researcher. A sample is subset of the population on which observation or measurement taken. This study used purposive sampling method. This is a non-probability sampling method of sampling. Considering the nature of the research, the purposive sampling method was selected as the most appropriate. A purposeful sampling method was used for the identification of company representatives as well as the customer groups. In this sampling method, the researcher considered the aim of the research and selected samples accordingly. Consumer representatives were selected using a systematic sampling technique where companies' data bases were used as sampling frames for this exercise. The sample size was determined largely through the use of Krejcie and Morgan's model of sample size determination.

\subsection{Questionnaire design}

The questionnaire was designed in a semi-structured manner around the stated research objectives in chapter one. This was deliberately done to ensure that only relevant questions which help in providing answers to research questions were asked. The semi-structured nature of the questionnaire allowed the use of both closed ended as well as open -ended questions. The use of open and closed questions was deliberately designed in order to be able to obtain both quantitative as well as qualitative data. This way, the researcher was able to triangulate the research results. The open questions were useful in exploring new areas or ones in which the researcher had limited knowledge since the respondents could answer however they wish. Conversely, closed questions enhanced comparability of answer since they are presented with a set of fixed alternatives from which they had to choose an appropriate answer. The draft questionnaire was initially be given to colleagues for scrutiny before it is presented to a few selected customers for further pilot testing. Amendments to the questionnaire were made accordingly resulting in designing of the final questionnaire to be used in this research.

\subsection{Validity and reliability of findings}

Reliability is defined as the extent to which results are consistent over time and an accurate representation of the total population under study. A Cronbach alpha value of 0,89 was obtained using SPSS, indicating that the research instrument was reliable. Validity determines whether the research truly measures that which it was intended to measure or how truthful the that research results are. For this reason, data triangulation was in order to control bias and 
establishing valid propositions because traditional scientific techniques are incompatible with this alternate epistemology. Consequently, the researcher combined both quantitative and qualitative techniques in gathering and analyzing research through the use of a semi-structured questionnaire as mentioned. By so doing, triangulation strengthened the study and thus increased its validity. The collected data was analyzed through the use of charts, tables, graphs, diagrams and also content analysis. This entailed a critical analysis of the responses given on order to extract meaning. Verbatim responses were analyzed in their raw state to extract information critical for decision making. Further, the researcher used the Statistical Package for Social Sciences (SPSS) for the analysis of various constructs in line with the research objectives.

\section{Findings}

While 9 questionnaires were sent to the sampled companies, one company representative did not complete the questionnaire at all. Of the remaining 8 questionnaires returned, one was not completed in full and was discarded as unusable leaving only 7 usable questionnaires drawn from the 9 representatives of the 3 companies as shown on Table 1 below. With respect to consumers, all 15 respondent, giving response rate of $100 \%$. Therefore, the overall response rate was calculated as $92 \%$.

Figure 1: Advances in automated call Centre and customer satisfaction and loyalty

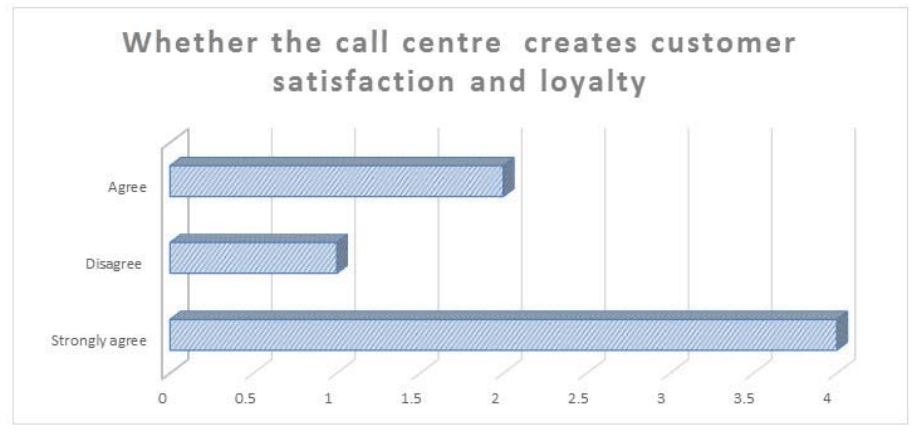

The majority of respondents confirmed the importance of an automated call center in the creation of customer satisfaction and loyalty. 4 out of the 7 representatives confirmed this while only one representative disagreed.

Figure 2: Subscriber data and customer satisfaction

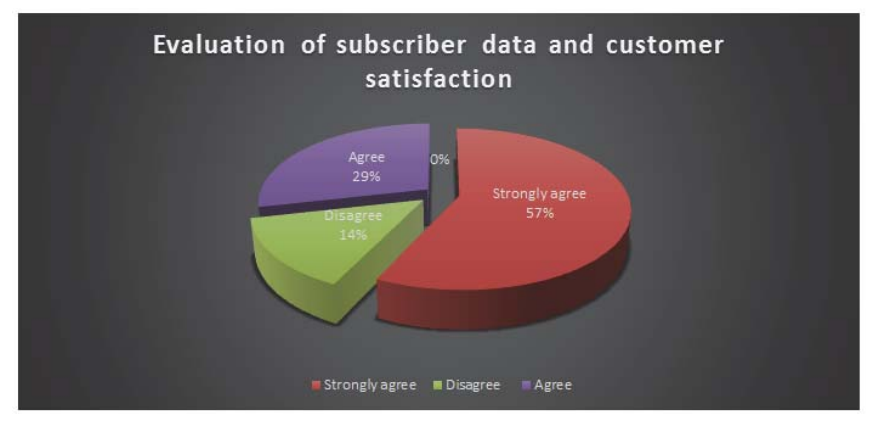

An almost similar result was obtained with respect to subscriber data and its role in the creation of customer satisfaction was shown on Figure 2 above. 57\% of the sampled company representatives indeed confirmed that subscriber data helps in building satisfied and a loyal customer base. Only one representative from company B disagreed while 2 agreed with the assertion. 
Figure 3: Subscriber data base and competitiveness

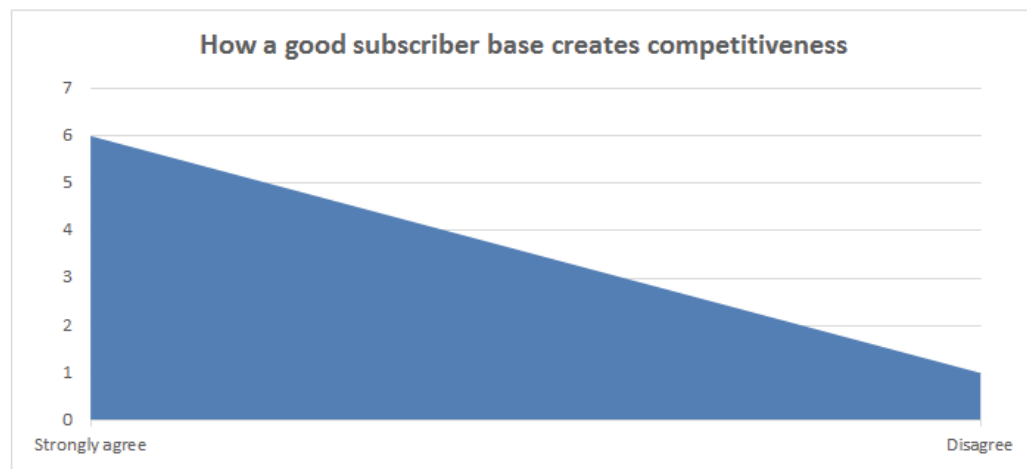

A good subscriber data base also helps in creating competitiveness in companies. 6 representatives of the 7 respondents strongly agreed with the question as shown on Figure 3 above. Only one respondent disagreed.

Figure 4: Spreading good messages

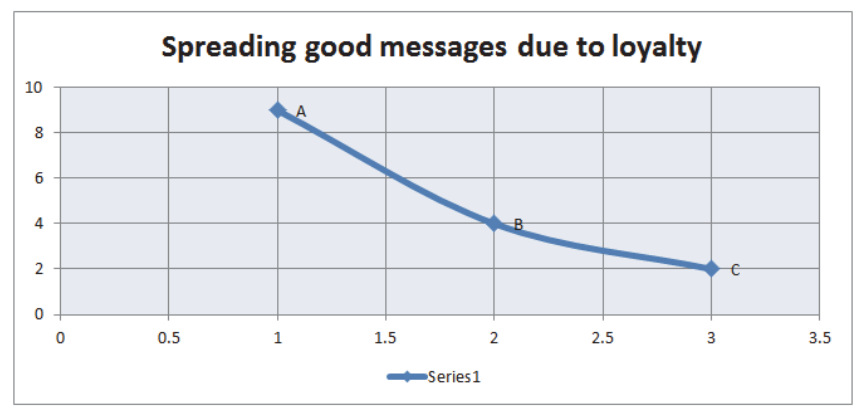

A follow-up up question revealed that those who had positively assessed the companies' CRM also confirmed that they will use the internet to spread good messages. This is because they are satisfied and thus loyal to their respective preferred companies. Company A was highly rated with 9 customers out of the sampled 15 confirming this as shown on Figure 4 above.

\section{Discussion}

Results of the research showed that because of the highly dynamic market environment, consumers have become highly demanding. This was demonstrated by 5 company representatives who strongly agreed that indeed the highly demanding customers are compelling them to upgrade their operational CRM. In support, a further 2 agreed that consumers are becoming more demanding than ever before. These results mean that companies have create more customer perceived value through CRM by engaging with them as closely as possible. The results are well supported by Creighton (2000), who noted that regardless of the channel or method used to contact the company, whether it is the Internet, call centers, sales representatives, or resellers, customers should receive the same consistent and efficient service as they are becoming highly demanding (Creighton, 2000). Moreover, results from the responses of company representatives showed that 6 out of the 7 representatives agreed that consumer perceived value is a function of the effort consumers put in the search of services and products and benefits they eventually obtain through such an engagement. Only one representative disagreed with this assertion. The implications are that as long as the company provides high value products, consumers are willing to put effort in searching for them as they will be eventually be rewarded (output) through satisfaction. Customer value is "the fundamental basis for all marketing activity" (Holbrook, 1994, p. 22).

Further, the perceived value of operational CRM was clearly demonstrated with the way how customers value company A's operational CRM. This was confirmed by 9 out 15 customer respondents while 4 respondents observed that company B provides the second best operational CRM as supported by 4 respondents. Company $C$ was evaluated last with only 2 customers favorably assessing the company's operational CRM. $57 \%$ of the respondents strongly agreed that 
their companies offered more than what consumers expected. The majority of these representatives were from the two biggest companies, namely companies $\mathrm{A}$ and $\mathrm{B}$. The results confirm the prediction that through operational CRM, customer perceived value is strengthened. This is an important prerequisite towards the creation of a loyal customer base.

The strategic significance of the intelligent network in CRM for the creation of customer satisfaction also confirmed the importance of the use of Intelligent Network for enhancing a company's CRM and hence the creation of a loyal customer base. $57 \%$ of the sampled company representatives indeed confirmed that Intelligent Network helps in building satisfied and a loyal customer base. Only one representative from company $\mathrm{C}$ disagreed while 2 agreed with the assertion. $57 \%$ of the sampled company representatives confirmed that subscriber data helps in building satisfied and a loyal customer base. Only one representative from company B disagreed while 2 agreed with the assertion. The interviewed customers observed company A's operational CRM is largely driven by its automated call centre. This was shown by $60 \%$ of the interviewed customers with company B being rated highly by $27 \%$ of the customers with the remainder (13\%) for company $\mathrm{C}$. Basing on these results, it is quite evident that technological innovations are at the centre of a well rated CRM which is able to build trust and commitment from customers and thus the generation of loyalty. There was an almost unanimous agreement that indeed a well-structured automated call centre creates competiveness. $86 \%$ of the sampled company representatives confirmed this. $14 \%$ of the interviewed respondents agreed that CRM through automating the call centre helps in creating competitive companies. A good subscriber data base also helps in creating competitiveness in companies. 6 representatives of the 7 respondents strongly agreed with the question as shown on Figure 12 above. Only one respondent disagreed. As was the case with the assessment of its automated call centre, Company A, the market leader, was highly commended with 9 out of the 15 representative customers interviewed. Company B was moderately evaluated with 4 customers and 2 customers for company $\mathrm{C}$. Positive evaluations on the competitiveness of companies help in the creation of strong brand associations and hence loyalty. Customer loyalty is one major driver of success in e-commerce (Reichheld \& Schefter, 2000). Loyal customers often will, over time, bring in substantial revenues and demand less time and attention from the firms they patronize. Many customers are inclined to forgive customer-service mishaps, display decreasing sensitivity to price, and disseminate positive word-of-mouth about the business to others (Reichheld \& Schefter, 2000). Results for company A clearly indicate why the company continues to dominate in the MTI. Since perceived value has its roots in equity theory, which considers the ratio of the consumer's outcome/input to that of the service provider's outcome/ input, operational CRM should seek to increase value (outcome) while the reduce the perceived costs (input). Perceived costs include monetary payments and nonmonetary sacrifices such as time consumption, energy consumption, and stress experienced by consumers. In turn, customer- perceived value results from an evaluation of the relative rewards and sacrifices associated with the offering. Customers are inclined to feel equitably treated if they perceive that the ratio of their outcome to inputs is comparable to the ratio of outcome to inputs experienced by the company. These results are well supported by several researchers, including Johnston (1998), Goodman and Newman (2002), and Chebat, Davidow, and Codjovi (2005) who concluded that the impact of the customer service experience on customer satisfaction and retention. One of the key finding from this stream of research is that the vast majority of dissatisfied customers do not complain but are nevertheless at much greater risk of abandoning their relationship with the company as a consequence of their unhappiness.

\section{Conclusions}

Various streams of literature argue that customer value is a super ordinate goal and customer loyalty is a subordinate goal, as it is a behavioural intention. According to goal and action identity theories, a super ordinate goal is likely to regulate subordinate goals. Thus, customer value regulates behavioural intentions of loyalty toward the service provider as long as such relational exchanges provide superior value and hence customer-perceived value has been found to be a major contributor to customer loyalty. In agreement with various streams of literature, the research results from this study further confirm that OCRM's major role is to automate the business processes underpinning the day-today tasks of sales, marketing, and service functions in order to optimize sales productivity by improving the speed and quality of information flow to improve internal communications between the sales force and management. OCRM is an influential strategy to gain competitive advantage in current market scenario. Company competitiveness can be obtained through managing companies' automated call centers, their intelligent networks and subscriber base in a way which is superior to competition. For CRM to be truly effective, an organization must first understand who its customers are and what their lifetime value (LTV) is. Therefore, operational CRM, if implemented with the customer in mind will most likely result in the creation of customer loyalty.

While current research focused on operational CRM's influence on customer loyalty, future research should assess 
the impact of analytical CRM on customer loyalty. The measurement and critical analysis of customer life time value against company investments in building loyalty should redirect future research towards this area.

\section{References}

Anderson, J. C., \& Narus, J. A., (1991). Partnering as a Focused Market Strategy. California Management Review, 95-113.

Anton, J., Setting, T., \& Gunderson, C., (2004). Offshore company call centers: A concern to U.S. consumers. Technical Report, Purdue. University Center for Customer-Driven Quality

Berman, S., Wicks, C., Kotha,S., \& Jones, T.M., (1999). Does Stakeholder Orientation Matter? The Relationship between Stakeholder Management Models and Firm Financial Performance, Academy of Management Journal, 42 (5), 488-506.

Berry, L. L., \& Parsuraman, A., (1991) . Marketing Services - Competing through Quality, New York: Free Press.

Berry, L. L., (1995). Relationship Marketing of Services, Growing Interest and Emerging Perspectives, Journal of the Academy of Marketing Science, 236-245.

Bitner, M., (1990). Evaluating Service Encounters: The effects of Physical Surroundings and Employee Responses, Journal of Marketing, 54, 69-82.

Bloemer, J., de Ruyter, K., \& Wetzels, M. (1999). Linking perceived service quality and service loyalty:A multi-dimensional perspective, European Journal of Marketing, 33, 1082-1106.

Bolton, R. N., \& Drew, J. H., (1991). A longitudinal analysis of the impact of services changes on customer attitudes, Journal of Marketing, 55, 1-9.

Bolton, R.N., \& Lemon, K.N., (1999).A dynamic model of customers' usage of services: Usage as an antecedent and consequence of satisfaction, Journal of Marketing Research, 36, 171-186.

Bolton,R.N.,\& Lemon,K.N.,(1999).A dynamic model of customers' usage of services: Usage as an antecedent and consequence of satisfaction, Journal of Marketing Research, 36, 171-186.

Bromiley, P., \& Marcus, A., (1989). The Deterrent to Dubious Corporate Behavior: Profitability, Probability, and Safety Recalls, Strategic Management Journal 10(3), 233-250.

Chang, H., (2007). Critical Factors and Benefits in the Implementation of Customer Relationship Management, Total Quality Management, 18 (5), 483-508.

Chang,T.Z.,\& Wildt,A.R.,(1994).Price, product information, and purchase intention: An empirical study, Journal of the Academy of Marketing Science, 22, 16-27.

Chebat, C., Davidow, M., and Codjovi, I., (2005). Silent Voices; Why Some Dissatisfied Consumers Fail to Complain, Journal of Service Research, 7 (4), 328-342.

Christou, E., (2000). Guest loyalty likelihood in relation to hotels' corporate image and reputation: A study of three countries in Europe, Journal of Hospitality \& Leisure Marketing, 10(1), 88-99.

Creighton, S., (2000). Partnering for success to the e-business world, in Proceedings of DC Customer Relationship Management Conference, Boston, MA.

Creswell, J. W., (2007). Educational research (3rd Ed.). Thousand Oaks, CA: Sage.

Cronin, J. J., \& Taylor, S. A. (1992). Measuring service quality: A re-examination and extension, Journal of Marketing, 56, 55-68.

Czepiel, J.A., \& Gilmore, R. (1987). Exploring the concept of loyalty in services. In J.A.Czepiel,C.A.Congram,\& J.Shanahan (Eds.), The services challenge: Integrating for competitive advantage. Chicago. IL: American Marketing Association.

Davidson, W. N., \& Worell, D.L., (1988). The Impact of Announcements of Corporate lllegalities on Share-holder Returns', Academy of Management Journal, 31 (1), 195-200.

Davis, F. D., Bagozzi, R. P., \& Warshaw, P. R.., (1989). User acceptance of computer technology: A comparison of two theoretical models, Management Science, 35,982-1003.

Davis,F.D.,(1989).Perceived usefulness, perceived ease of use, and user acceptance of information technology. MIS Quarterly, 13, 319340.

Doyle, S. X., \& Roth, G. T., (1992) .Selling and Sales Management in Action: The Use of Insight Coaching to Improve Relationship Selling, Journal of Personal Selling \& Sales Management, 59-64.

Dwyer, F. R., Schurr, P.H., \& Oh, S., (1987). Developing Buyer-Seller Relationships, Journal of Marketing, 51, 11-27.

Eichfeld, A., Morse, T.D., and Scott, K.W., (2006). Using Call Centers to Boost Revenue, McKinsey Quarterly, 1-7.

Fletcher, K. and Wright G., (1996). The strategic context for information systems use; an empirical study of the financial services industry, International Journal of Information Management, 16 (2), 119-131.

Fornell, C., Sunil, M., Forrest, V. M., \& Krishnan, B., (2006). Customer satisfaction and stock prices: high returns, low risk, Journal of Marketing, 70, January, 3-14.

Frooman, J., (1997). , Socially Irresponsible and Illegal Behavior and Shareholder Wealth: A Meta-Analysis of Event Studies, Business \& Society36 (3), 221-249.

Ganesan, S., (1994). Determination of Long-Term Orientation in Buyer Seller Relationships, Journal of Marketing, 58, 1-19.

Gans, A., (20020. Customer loyalty and supplier quality competition, Management Science 48(2) 207-221.

Gillies, G., Rigby, D., \& Reichheld, F., (2002). The story behind successful customer relationship management, European Business Journal, 14 (2), 73-77.

Goldenberg, B., (2000). What is CRM? What is an e-customer? Why you need them now, in Proceedings of DCI Customer Relationship 
Management Conference, Boston, MA

Goodman, J., \& Newman, S., (2003). Understand customer behavior and complaints, Quality Progress, 36(1), 51-55.

Gronroos, C., (1990). Relationship Approach to Marketing in Service Contexts: The Marketing and Organizational Behaviour Interface, Journal of Business Research, 20, 3-11.

Gulati, R., and Garino, J., (2000). Get the Right Mix of Bricks \& Clicks, Harvard Business Review, 78(3), 107-114.

Gummesson, E., (2002). Total relationship marketing (2nd Ed.). Oxford: Butterworth- Heinemann/Chartered Institute of Marketing.

Holbrook,M.B.,(1994). The nature of customer's value: An axiology of service in consumption experience. In R. T. Rust, \& R. L. Oliver

(Eds.), Service quality: New directions in theory and practice. Thousand Oaks, CA: Sage Publications.

Jackson, B. B., (1985). Winning and Keeping Industrial Customers: The Dynamics of Customer Relationships. Lexington, MA: D.C.

Kassanoff, B. (2000). Build loyalty into your e-business", in Proceedings of DCI Customer

King, S., and Burgess, T., (2008), Understanding success and failure in customer relationship management, Industrial Marketing Management, 37(7), 721-431.

Levine, S., (2000). The rise of CRM , America's Network, 4(6) , 34-44.

Lo, A.S., Stalcup, L.D., Lee, A., (2010), Customer relationship management for hotels in Hong Kong, International Journal of Contemporary Hospitality Management, 22(2), 139-159.

McKenna, R., (1991). Relationship Marketing: Successful Strategies for the Age of the Customers. Addison-Wesley.

Morgan, R. M., \& Hunt, S. D., (1994). The Commitment-Trust Theory of Relationship Marketing, Journal of Marketing, 58 (3), 20-38.

Neal,W.D.,(1999).Satisfaction is nice,but value drives loyalty, Marketing Research, 21-23.

Nguyen T. H., Joseph S. S., \& Michael N., (2007). Strategies for successful CRM Implementation, Journal of Information Management \& Computer Security, 15 (2), 102-115.

Oliver, R. L., (1999). Whence Consumer Loyalty, Journal of Marketing, 63, 33-44.

Oliver, R.L., \& DeSarbo, W.S., (1988).Response determinants in satisfaction judgments, Journal of Consumer Research, 14, 495-508.

Olsen, M.D., Connolly, D.J., (2000). Experience-based travel. How technology is changing the hospitality industry, Cornell Hotel and Restaurant Administration Quarterly, 30 -40.

O'Neal, C. R., (1989). JIT Procurement and Relationship Marketing, Industrial Marketing Management, 18, 55-63.

Parasuraman, A., \& Grewal, D. (2000). The impact of technology on the quality-value-loyalty chain: A research agenda, Journal of Academic of Marketing Science, 28, 168-174.

Paul, T., (1988). Relationship Marketing for Health Care Providers, Journal of Health Care Marketing, 8, 20-25.

Peppers, D., \& Rogers, M., (1993). The One to One Future: Building Relationships One Customer at a Time. New York: Doubleday.

Piccoli, G., O'Connor, P., Capaccioli, C., \& Alvarez, R., (2003).Customer relationship management: A driver for change in the structure of the U.S. lodging industry, Cornell Hotel and Restaurant Administration Quarterly, 44, 61-73.

Piskar, F., Faganel, A., (2009). A Successful CRM Implementation Project in a Service Company: Case Study, Journal of Management, Informatics and Human Resources, 42(5) 199-208.

Reichheld F. F., (1996). The Loyalty Effect. Boston, MA: Harvard Business School Press

Reichheld, F.F., Markey, R.G., \& Hopton, C. (2000).E-customer loyalty-applying the traditional rules of business for online success, European Business Journal, 12, 173-179.

Relationship Management Conference, Boston, MA.

Rosenberg, L., \& Czepiel, J., (1984). A Marketing Approach to Customer Retention." Journal of Consumer Marketing, 45-51.

Shani, D., \& Chalasani, S., (1992). Exploiting Niches Using Relationship Marketing, Journal of Consumer Marketing, 9 (3), 33-42.

Sheth, J. N., Mittal, B., \& Newman, B. I., (1999). Consumer Behaviour and Beyond. Fort Worth, TX: The Dryden Press.

Sigala, M., (2005). Integrating customer relationship management in hotel operations: Managerial and operational implications, International Journal of Hospitality Management, 24(3), 391-413.

Sirdeshmukh, D., Singh, J., \& Sabol, B. (2002). Consumer trust, value, and loyalty in relational exchanges, Journal of Marketing, 66, 1537.

Storbacka, K., (2000). Customer Profitability: Analysis and Design Issues. In J. N. Sheth \& A. Parvatiyar (Eds.), Handbook of Relationship Marketing (565- 586). Thousand Oaks, CA: Sage Publications.

Sun, B., (2006). Technology Innovation and Implications on Customer Relationship Management-Comments on Marketing Models of Service and Relationships [Invited Commentary]. Forthcoming, Marketing Science.

Waddock, S.A., \& Graves S.M., (1997).The Corporate Social Performance-Financial Performance Link, Strategic Management Journal, 18(4), 303-319.

Wells, J.D., William, L.F., Choobineh, J., (1999). Managing information technology for one to-one customer interaction, Information and Management, 35 (1), 53-62.

Wetsch, L. R., (2006). Trust, Satisfaction and Loyalty in Customer Relationship Management, Journal of Relationship Marketing, 4 (3), 29-42.

Winer, R. S., (2001). A framework for customer relationship management, California Management Review, 43(4), 89-105.

Zablah, A. R., Bellenger, D. N., \& Joh, W. J., (2004). An evaluation of divergent perspectives on customer relationship management: Towards a common understanding of an emerging phenomenon, Industrial Marketing Management, 33, 475- 489.

Zeithaml, V.A., Berry, L.L., \& Parasuraman, A., (1996).The behavioral consequences of service quality, Journal of Marketing, 60, 31-46. 